\title{
Phylogenetic Study of Zebrafish (Amatitlania nigrofasciata) as an Introduction Spesies in Buyan Lake
}

\author{
Bachori Dhian Pratama a*, Pande Gde Sasmita Julyantoro a, Made Ayu Pratiwi a \\ a Department of Aquatic Resources Management, Faculty of Marine and Fisheries, Udayana University, Jimbaran, Badung, Bali-Indonesia \\ * Correspondent author. Tel.: +62-858-4729-4728 \\ E-mail address: bachoripratama@gmail.com
}

Received (diterima) 24 April 2018; accepted (disetujui) 16 September 2018; available online (tersedia secara online) 20 September 2018

\begin{abstract}
Abstrak
Danau Buyan memiliki beberapa komoditas perikanan yang sering dijumpai antara lain Ikan Zebra (Amatitlania nigrofasciata). Hingga saat ini, asal asli keberadaan Ikan Zebra di Danau Buyan belum diketahui sehingga perlu dilakukan penelitian untuk mengetahui kepastian jenis, filogenetik, keragaman haplotipe, dan karakteristik fenotipe. Penelitian dilaksanakan dari bulan Januari sampai Februari 2018. Identifikasi molekuler dilakukan di Laboratorium Biodiversity Indonesia Bali. Penelitian ini menggunakan metode deskriptif kuantitatif dan kualitatif. Pengambilan sampel dilakukan secara simple random sampling dari hasil tangkapan nelayan. Sampel sirip Ikan Zebra digunakan untuk identifikasi molekuler dan morfologi Ikan Zebra untuk identifikasi morfologi. Hasil penelitian menunjukkan seluruh sekuen sampel berhasil teramplifikasi dengan gen Cytochrome Oxidase subunit I (COI) sebesar 620 bp. Jarak genetik seluruh sekuen Ikan Zebra Danau Buyan sebesar 0 yang berarti bahwa sekuen dari seluruh sampel adalah sama dan merupakan satu spesies Amatitlania nigrofasciata dengan perhitungan jarak genetik 0. Sekuen Ikan Zebra Danau Buyan berkerabat dekat dengan Amatitlania nigrofasciata KU568740, Amatitlania nigrofasciata KU568739, Amatitlania nigrofasciata KU568737, Amatitlania nigrofasciata KJ552531, dan Amatitlania nigrofasciata KU568738 dengan jarak genetik 0 dan berkerabat jauh dengan Rocio ostofasciata EU751752 dengan jarak genetik 0,113. Keragaman haplotipe sekuen Ikan Zebra di Danau Buyan adalah 0 yang termasuk keragaman haplotipe rendah. Ikan Zebra Hitam dan Hitam Totol berada di clade yang berbeda dengan Ikan Zebra Albino dan Albino Totol dengan nilai bootstrap 100 sehingga terdapat perbedaan secara fenotipe.
\end{abstract}

Keywords: COI; filogenetik; ikan zebra

\begin{abstract}
Buyan Lake has some fishery commodities which were often encountered include the Zebrafish (Amatitlania nigrofasciata). The origin existence of Zebrafish in Buyan Lake is not yet known then it needs study in order to know the certainty of species, phylogenetic, haplotype diversity, and phenotype characteristic. The study was conducted from January to February 2018. Molecular identification was done at Laboratory of Biodiversity Indonesia Bali. This research used quantitative and qualitative descriptive methods. Sampling was done by simple random sampling from fisherman catches. Zebrafish's fin samples were used for molecular identification and Zebrafish's morphological for morphological identification. The results showed that the entire sequence samples were successfully amplified with the Cytochrome Oxidase subunit I (COI) gene of $620 \mathrm{bp}$. The genetic distance in the entire Zebrafish sequences in Buyan Lake of 0 which means that the sequence of all samples are exactly similiar as species of Amatitlania nigrofasciata with the genetic distance calculation of 0 . Sequence of Zebrafish in Buyan Lake is closely related to Amatitlania nigrofasciata KU568740, Amatitlania nigrofasciata KU568739, Amatitlania nigrofasciata KU568737, Amatitlania nigrofasciata KJ552531, and Amatitlania nigrofasciata KU568738 with genetic distance of 0 and has a distant relation with Rocio ostofasciata EU751752 with genetic distance of 0.113 . The haplotype diversity of Zebrafish sequences in Buyan Lake showed the value of 0 which belongs to a low haplotype diversity. Black and Black Zebrafish with Red Spotted are in a different clade with Albino and Albino Zebrafish with Red Spotted with bootstrap value of 100, means they have phenotypically differences.
\end{abstract}

Kata Kunci: COI; phylogenetic; zebrafish 


\section{Introduction}

The lake is one of the surface water resources in Bali Island that supports tourism, social, and economic activities. One of the lakes located on the Bali Island is Buyan Lake. Buyan Lake has fishery commodities which were often encountered include Nilafish (Oreochromis niloticus) and Zebrafish (Amatitlania nigrofasciata) (Restu et al., 2015; Sravishta et al., 2017).

Type of Zebrafish (Amatitlania nigrofasciata) is the most dominant fishery resources in Buyan Lake (Restu, et al., 2015). The commodities are caught in the net by local fishermen. Zebrafish is an invasive species that has high invasive potential and can affect the life of endemic species (Sentosa and Wijaya, 2013). This causes the presence of Zebrafish to affect the catch of the local community. The existence of Zebrafish in Buyan Lake is not yet known the origin of the fish then it needs molecular identification study.

Molecular identification with deoxyribonucleic acid (DNA) barcoding technique can be used to help identify species including invasive species. This technique is widely developed to identify species, because it is relatively easy to be compared to other techniques (Wong and Hanner, 2008). Molecular identification can know the phylogenetic of a fish population in an area. Phylogenetic is a method that often used in almost all branches of biology for genome comparison and for knowing relationship between species based on living trees through the calculation of basic sequence statistic (Yang and Rannala, 2012).

One method that can be used to determine the phylogenetic in animals is using the gene encoding Cytochrome Oxidase subunit I (COI). The COI gene in mitochondrial DNA can be used as a molecular marker for species determination. According to Buhay (2009) that COI is one of the most helpful method for identifying kinship in animal and fish species. The used of COI gene to differentiate species had been done in several species of animal for example in mantis shrimp, shellfish, silkworm, insects, cattle and some species of fish. According to Kurniasari et al. (2014) COI gene is a genetic marker that has high evolutionary level and can be used to differentiate in close kinship.

Publication of phylogenetic study on Amatitlania nigrofasciata in Buyan Lake with COI method has not been reported, then it is necessary to do research to know the phylogenetic of Amatitlania nigrofasciata in Buyan Lake. This will be useful as a data base for identifying mutated and specific nucleotide sites in the same species with different locations.

\section{Methods}

\subsection{Time and Location}

This research was done in Buyan Lake, located on Pancasari Village, Sukasada District, Buleleng Regency, Bali Province (Figure 1). Data collection was done in January 2018. Fish samples that have been obtained are then carried out molecular identification at Laboratory of Biodiversity Indonesia (Bionesia) Bali.

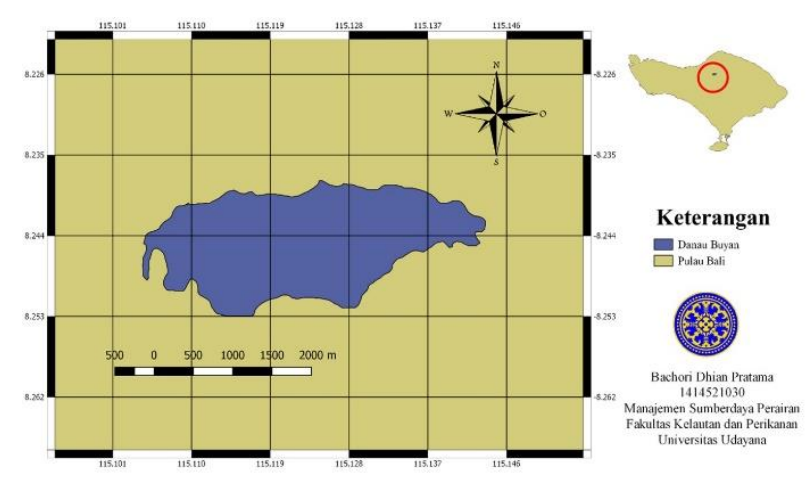

Figure 1. Research location

\subsection{Tools and Materials}

The research tools used include: Bunsen flame, tweezers, tray, microtube $0.6 \mathrm{ml}$, heatingblock, vortex, centrifuge, glove, PCR strip tube, PCR machine, $100 \mu \mathrm{L}$ pipettes, $10 \mu \mathrm{L}$ pipettes, yellow tip, $10 \mu \mathrm{L}$ tip, LED transilluminator, analytical scales, beaker, microwave, mold, comb, electrophoresis machine, digital camera, $1.6 \mathrm{ml}$ microtube, cool box, stationery, microscope, calipers, and parafilm paper. Materials needed in this study include: $96 \%$ ethanol, $10 \%$ chelex solution, ddH2O solution, Cytochrome Oxidase subunit I (COI) locus, master mix solution (KAPA), agarose powder, biotium, SB Buffer solution, low mass DNA ladder, Formalin 5\%, and Zebrafish (Amatitlania nigrofasciata).

\subsection{Research Methods}

This research used descriptive method with quantitative and qualitative approach. Descriptive research is a research that describes the number of 
related variables to the problem and the unit that be researched (Mulyadi, 2011). Quantitative research is used to examine a particular population or sample, sampling technique is generally done randomly, data collection using a research instrument (Hayati, 2015). While qualitative research is a method to analyze the factors related to the object by presenting the data more depthly to the object of research (Prabowo and Heriyanto, 2013).

\subsubsection{Sampling}

Zebrafish samples were taken from fisherman catches. Samples were taken by simple random sampling (Table 1). According to Nurhayati (2008) simple random sampling is a method that used to select the sample of the population which the members of the population have an equal opportunity to be taken as a sample.

Table 1

Number of samples

\begin{tabular}{cccc}
\hline $\begin{array}{c}\text { Type of } \\
\text { fish } \\
\text { sample }\end{array}$ & ID & $\begin{array}{c}\text { Identification } \\
\text { molecular's } \\
\text { sample }\end{array}$ & $\begin{array}{c}\text { Identification } \\
\text { morphology's } \\
\text { sample } \\
\text { (quantity) }\end{array}$ \\
\hline Black & HITAM & 07 ZB & 15 \\
& & $17 \mathrm{ZB}$ & \\
Black & HITAM & $12 \mathrm{ZB}$ & \\
with red & TOTOL & $06 \mathrm{ZM}$ & 15 \\
spotted & & $20 \mathrm{ZM}$ & \\
Albino & ALBINO & $08 \mathrm{ZA}$ & 15 \\
Albino & ALBINO & $17 \mathrm{ZA}$ & 15 \\
with red & TOTOL & $20 \mathrm{ZA}$ & \\
spotted & & & 60 \\
\hline \multicolumn{2}{c}{ Quantity } & 9 & \\
\hline
\end{tabular}

\subsubsection{Identification of Morphological Character}

Identification of morphological character is used as a comparison with molecular identification. Identification of morphological character includes measurement of meristic character refers to Samaradivakara et al. (2012) with some modifications that refer to Fishbase (2018). While the calculation of morphometric character refers to Fishbase (2018). As a supporter of morphological character of fish also conducted observation of body shape, shape of tail fin, type of scales, location of fish mouth refer to Rahayu et al. (2013) with some modifications that refer to Fishbase (2018).

\subsubsection{Fish's Fin Sampling}

Sampling to be identified molecularly was taken at the Zebrafish's pectoral fin. Samples of fish's fins brought to the laboratory for molecular identification were placed in 1,6 ml microtubes which were given $96 \%$ ethanol solution. The used of $96 \%$ ethanol solution as preservation was done to prevent the destruction of the DNA composition on the sample. Next, the sample was labeled and putted into the cool box.

\subsubsection{Identification of Molecular Character}

\section{a. Extraction}

DNA extraction was done by using $10 \%$ chelex solution. The tissue sample was taken as $\pm 2 \mathrm{~mm}$ used tweezers and inserted into a tube contained chelex solution. Before and after being used for tissue picking, tweezers were immersed in $96 \%$ ethanol and burned with bunsen flame. Chelex solution that had been filled in tissue was vortexed and centrifuged for 15 seconds, then heated with temperature $95^{\circ} \mathrm{C}$ for 45 minutes. Once heated, the tube was re-vortexed and centrifuged for 15 seconds.

\section{b. Polymerase Chain Reaction (PCR)}

Extracted DNA was used as a template for amplification at COI locus. Primer used in this study as in Table 2 (Baldwin et al., 2009). Amplification was done by using parameters which were pre-denaturation $94^{\circ} \mathrm{C}$ for 180 seconds, denaturation $94^{\circ} \mathrm{C}$ for 30 seconds, annealing $50^{\circ} \mathrm{C}$ for 30 seconds, extension $72^{\circ} \mathrm{C}$ for 60 seconds, post extension $72^{\circ} \mathrm{C}$ for 120 seconds. The denaturation until extension was repeated in 38 PCR cycles. Then the temperature dropped to $24^{\circ} \mathrm{C}$ for 60 seconds.

\section{Table 2}

Primer for amplification

\begin{tabular}{cl}
\hline \multicolumn{1}{c}{ Primer } & \multicolumn{1}{c}{ Base sequence } \\
\hline Fish-BCL & 5' TCA ACY AAT CAY AAA GAT ATY \\
& GGC AC '3 \\
Fish-BCH & 5' ACT TCY GGG TGR CCR AAR AAT \\
& CA '3 \\
\hline
\end{tabular}

\section{c. DNA visualization}

The amplified DNA was visualized by electrophoresis in 1\% agarose gel on SB buffer (sodium boric acid) with Biotium $(3 \mu \mathrm{l})$. 


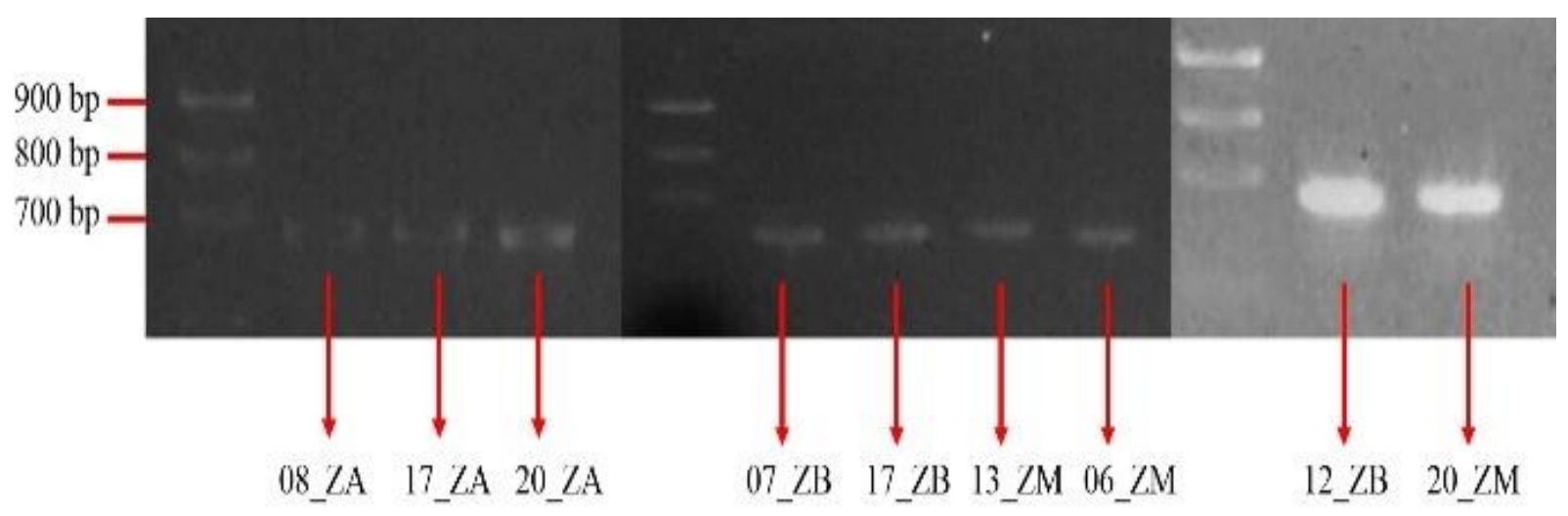

Figure 2. Results of eletrophoresis visualization

Electrophoresis was done at voltage of $100 \mathrm{~V}$ and current of $200 \mathrm{~mA}$ for 30 minutes and DNA was observed with a LED transilluminator. DNA size of PCR results compared with ladder to determine the length of DNA sample. Ladder used low mass ladder, with lengths 100-1000 bp.

\section{d. Sequensing}

The amplified DNA was prepared for the process of determining the sequence of nucleotides used a DNA sequencer. DNA sequencing was performed at the University of California, Barkeley on the sequencing facility. Sequensing was done by Sanger method.

\subsection{Data Analysis}

The sequenced data was processed by using the Molecular Evolutionary Genetic Analysis 7 (MEGA 7) program. The base sequences of DNA sequencing results were verified by the similarity with the COI gene of the Genus Amatitlania in the gene bank (http://blast.ncbi.nlm.nih.-gov) using the Basic Local Alignment Search Tool (BLAST) method. The sequencing results were aligned by using Clustal $\mathrm{W}$ to determine whether the homologous sequence results with other sequences (Kumar et al., 2016). Phylogenetic tree was made by using MEGA 7 software, with neighbor-joining method, p-distance model, and bootstrap 1000 replication. The genetic distance between species can be known through MEGA 7 software by using the pairwise distances method. The diversity of haplotype was known by DNA SP6 software.

Meristic and morphometric data were computed the standard deviation (Choudhury et al., 2011). The result of morfometric measurement was compared with the total length (TL) to obtain the ratio. The results of ratio's calculation of morphometric characters, the calculation of meristic characters, and the support character of the morphological (body shape, the shape of the caudal fin, the type of scales, the location of the mouth) were analyzed by using PAST 3.1 software program with UPGMA method, Bray-Curtis similarity index with bootstrap 1000 replication to get a dendogram based on morphological characters.

\section{Results and Discusion}

\subsection{Certainty of Type and Phylogenetic}

The electrophoresis visualization results showed all positive samples and the length of the successfully amplified COI gene was $<700$ bp (Figure 2). According to Wardani et al. (2017) the successful of DNA amplification is based more on primer conformity as well as the efficiency and optimization of the PCR process. Based on this, the primer of Fish BCL-BCH used successfully on the Amatitlania sample.

Based on sequencing results of the Amatitlania nigrofasciata with COI gene and the alignment results with the forward and reverse primers, obtained the nucleotide length which were Zebrafish $07 \mathrm{ZB}$ of $657 \mathrm{bp}, 17 \mathrm{ZB}(670 \mathrm{bp}), 13 \mathrm{ZM}$ (672 bp), 06 ZM (669 bp) , 12 ZB (625 bp), 20 ZM (670 bp), $08 \mathrm{ZA}(627 \mathrm{bp}), 17 \mathrm{ZA}$ (648 bp), and $20 \mathrm{ZA}(626$ $\mathrm{bp})$. The entire nucleotide sequence was be aligned and trimed to obtain nucleotide of $620 \mathrm{bp}$.

Based on the use of BLAST, obtained the score of 1125 and E. value of 0 , these indicate the homology level between the sample sequence data with 
Table 3

Matrix of genetic distance based pairwaise distance method

\begin{tabular}{|c|c|c|c|c|c|c|c|c|c|c|c|c|c|c|c|c|c|c|c|}
\hline & 1 & 2 & 3 & 4 & 5 & 6 & 7 & 8 & 9 & 10 & 11 & 12 & 13 & 14 & 15 & 16 & 17 & 18 & 19 \\
\hline \multicolumn{20}{|l|}{1} \\
\hline 2 & 0,000 & & & & & & & & & & & & & & & & & & \\
\hline 3 & 0,000 & 0,000 & & & & & & & & & & & & & & & & & \\
\hline 4 & 0,000 & 0,000 & 0,000 & & & & & & & & & & & & & & & & \\
\hline 5 & 0,000 & 0,000 & 0,000 & 0,000 & & & & & & & & & & & & & & & \\
\hline 6 & 0,000 & 0,000 & 0,000 & 0,000 & 0,000 & & & & & & & & & & & & & & \\
\hline 7 & 0,000 & 0,000 & 0,000 & 0,000 & 0,000 & 0,000 & & & & & & & & & & & & & \\
\hline 8 & 0,000 & 0,000 & 0,000 & 0,000 & 0,000 & 0,000 & 0,000 & & & & & & & & & & & & \\
\hline 9 & 0,000 & 0,000 & 0,000 & 0,000 & 0,000 & 0,000 & 0,000 & 0,000 & & & & & & & & & & & \\
\hline 10 & 0,000 & 0,000 & 0,000 & 0,000 & 0,000 & 0,000 & 0,000 & 0,000 & 0,000 & & & & & & & & & & \\
\hline 11 & 0,000 & 0,000 & 0,000 & 0,000 & 0,000 & 0,000 & 0,000 & 0,000 & 0,000 & 0,000 & & & & & & & & & \\
\hline 12 & 0,000 & 0,000 & 0,000 & 0,000 & 0,000 & 0,000 & 0,000 & 0,000 & 0,000 & 0,000 & 0,000 & & & & & & & & \\
\hline 13 & 0,000 & 0,000 & 0,000 & 0,000 & 0,000 & 0,000 & 0,000 & 0,000 & 0,000 & 0,000 & 0,000 & 0,000 & & & & & & & \\
\hline 14 & 0,000 & 0,000 & 0,000 & 0,000 & 0,000 & 0,000 & 0,000 & 0,000 & 0,000 & 0,000 & 0,000 & 0,000 & 0,000 & & & & & & \\
\hline 15 & 0,002 & 0,002 & 0,002 & 0,002 & 0,002 & 0,002 & 0,002 & 0,002 & 0,002 & 0,002 & 0,002 & 0,002 & 0,002 & 0,002 & & & & & \\
\hline 16 & 0,073 & 0,073 & 0,073 & 0,073 & 0,073 & 0,073 & 0,073 & 0,073 & 0,073 & 0,073 & 0,073 & 0,073 & 0,073 & 0,073 & 0,071 & & & & \\
\hline 17 & 0,113 & 0,113 & 0,113 & 0,113 & 0,113 & 0,113 & 0,113 & 0,113 & 0,113 & 0,113 & 0,113 & 0,113 & 0,113 & 0,113 & 0,111 & 0,107 & & & \\
\hline 18 & 0,004 & 0,004 & 0,004 & 0,004 & 0,004 & 0,004 & 0,004 & 0,004 & 0,004 & 0,004 & 0,004 & 0,004 & 0,004 & 0,004 & 0,002 & 0,073 & 0,113 & & \\
\hline 19 & 0,002 & 0,002 & 0,002 & 0,002 & 0,002 & 0,002 & 0,002 & 0,002 & 0,002 & 0,002 & 0,002 & 0,002 & 0,002 & 0,002 & 0,000 & 0,071 & 0,111 & 0,002 & \\
\hline 20 & 0,002 & 0,002 & 0,002 & 0,002 & 0,002 & 0,002 & 0,002 & 0,002 & 0,002 & 0,002 & 0,002 & 0,002 & 0,002 & 0,002 & 0,000 & 0,071 & 0,111 & 0,002 & 0,000 \\
\hline
\end{tabular}

Explanation: 1. Amatitlania nigrofasciata 07 ZB FISHBCL BD, 2. Amatitlania nigrofasciata 17 ZB FISHBCL BD, 3. Amatitlania nigrofasciata $13 \mathrm{ZM}$ FISHBCH BD, 4. Amatitlania nigrofasciata $06 \mathrm{ZM}$ FISHBCL BD, 5. Amatitlania nigrofasciata $12 \mathrm{ZB}$ FISHBCL BD, 6. Amatitlania nigrofasciata $20 \mathrm{ZM}$ FISHBCH BD, 7. Amatitlania nigrofasciata 08 ZA FISHBCL BD, 8. Amatitlania nigrofasciata 17 ZA FISHBCL BD, 9. Amatitlania nigrofasciata 20 ZA FISHBCL BD, 10. Amatitlania nigrofasciata KU568740, 11. Amatitlania nigrofasciata KU568739, 12. Amatitlania nigrofasciata KU568737, 13. Amatitlania nigrofasciata KJ552531, 14. Amatitlania nigrofasciata KU568738, 15. Amatitlania coetepeque KJ820801, 16. Amphilophus citrinellus JN024798, 17. Rocio ostofasciata EU751752, 18. Amatitlania siqua KJ820797, 19. Amatitlania coatepeque KJ820809, 20. Amatitlania coatepeque KJ820803

sequence data on NCBI is quite good. According to Isda and Chaidamsari (2013) the BLAST analysis is done by looking at more than 150 score and E. values that are less than 10-4 or close to zero (0), then the resulting homology level is quite good. The higher of the score (bits) it shows that the homology level is better, then the lower of the $\mathrm{E}$. value indicates the better of the homology level. Query cover showing query alignment, the results showed the highest value of $98 \%$ in isolate sample with Amatitlania nigrofasciata KU568740. According to Nuryadi et al. (2016) query is a species that has similarities to sequence of DNA base of isolate.

The result of identification was also supported by the sequence of analyzed bases with BLAST program that obtained $100 \%$ identification value between all sequences of Zebrafish in Buyan Lake with Amatitlania nigrofasciata KU568740 which categorized has high homology level. This suggests that the results of molecular identification are particularly appropriate in distinguishing species to the sequence of DNA bases obtained from another sequences found in the gene bank.

The BLAST result was supported by reconstruction phylogenetic tree of using neighborjoining (NJ) method, p-distance model, bootstrap 1000 replication which gives information that individual Amatitlania nigrofasciata 07 ZB FISHBCL $\mathrm{BD}$, Amatitlania nigrofasciata 17 ZB FISHBCL BD, Amatitlania nigrofasciata $13 \mathrm{ZM}$ FISHBCH BD,
Amatitlania nigrofasciata 06 ZM FISHBCL BD, Amatitlania nigrofasciata 12 ZB FISHBCL BD, Amatitlania nigrofasciata $20 \mathrm{ZM}$ FISHBCH BD, Amatitlania nigrofasciata 08 ZA FISHBCL BD, Amatitlania nigrofasciata 17 ZA FISHBCL BD, Amatitlania nigrofasciata 20 ZA FISHBCL BD are in a same branching with Amatitlania nigrofasciata KU568740, Amatitlania nigrofasciata KU568739, Amatitlania nigrofasciata KU568737, Amatitlania nigrofasciata KJ552531, and Amatitlania nigrofasciata KU568738 with bootstrap value of 64 (Figure 3). The value of bootstrap 64 indicates that the repetition of the analyzes performed will change the branching of trees. According to Lemey et al. (2009) that a bootstrap value higher than 70 indicates that the data is relatively stable, it means good in $\mathrm{NJ}$ analysis.

The certainty of the type of Amatitlania nigrofasciata in Buyan Lake was evidenced by the existence of the genetic distance matrix (Table 3). The matrix shows that Amatitlania nigrofasciata 07 ZB FISHBCL BD, Amatitlania nigrofasciata $17 \mathrm{ZB}$ FISHBCL BD, Amatitlania nigrofasciata 13 ZM FISHBCH BD, Amatitlania nigrofasciata $06 \mathrm{ZM}$ FISHBCL BD, Amatitlania nigrofasciata 12 ZB FISHBCL BD, Amatitlania nigrofasciata $20 \mathrm{ZM}$ FISHBCH BD, Amatitlania nigrofasciata $08 \mathrm{ZA}$ FISHBCL BD, Amatitlania nigrofasciata 17 ZA FISHBCL BD, Amatitlania nigrofasciata $20 \mathrm{ZA}$ FISHBCL BD have a genetic distance from each other of 0 . Based on that result, Black Zebrafish, 


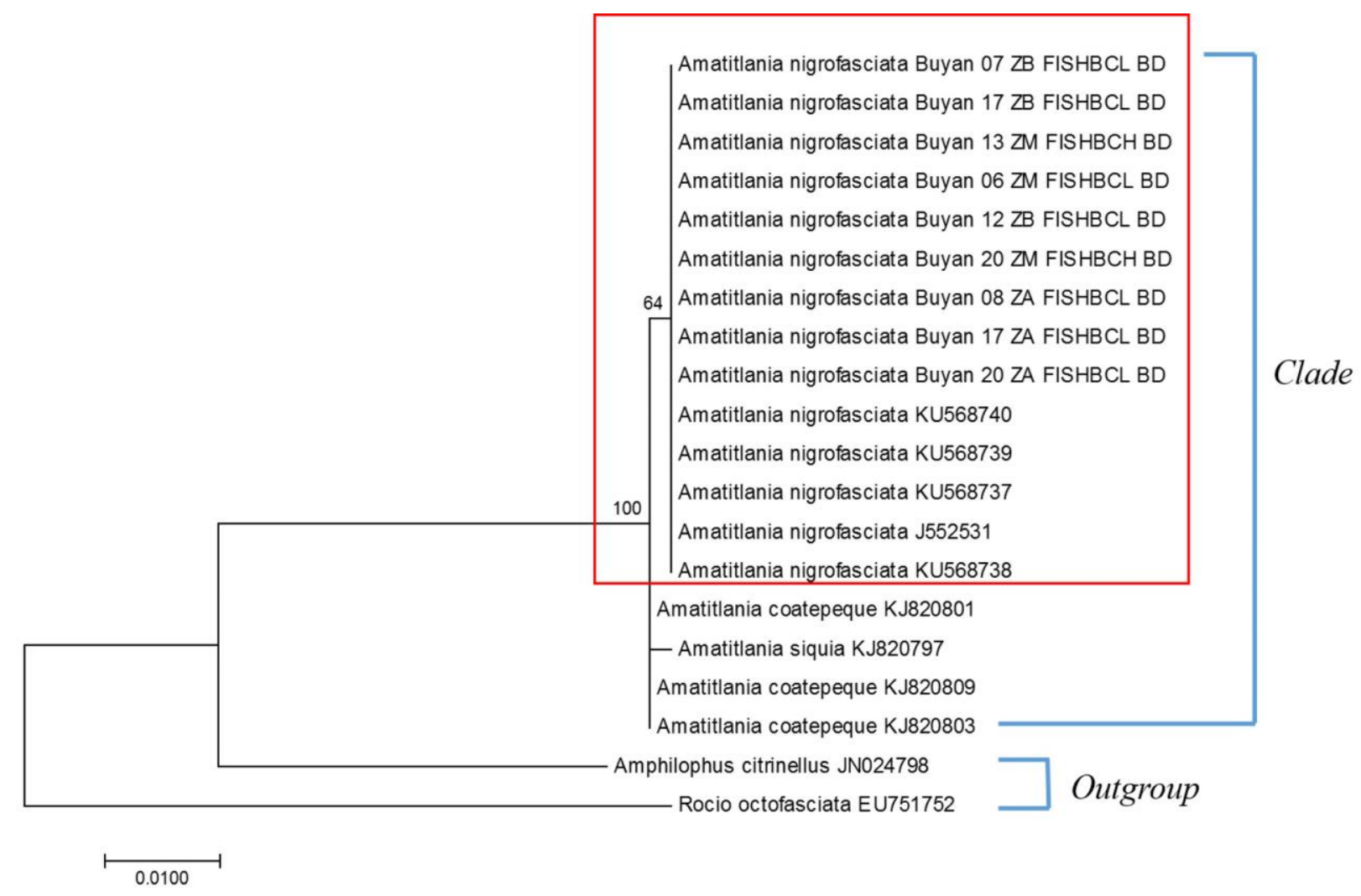

Figure 3. Reconstruction of phylogenetic tree based on COI gene

Black Zebrafish with Red Spotted, Albino Zebrafish and Albino Zebrafish with Red Spotted are the same species.

\section{Table 4}

Nucleotide variation of Zebrafish in Buyan Lake

\begin{tabular}{|c|c|c|c|c|c|c|c|c|c|}
\hline \multirow{2}{*}{ Sample } & \multicolumn{9}{|c|}{ Nucleotide base's position } \\
\hline & 1 & 2 & 3 & & & & 618 & 619 & 620 \\
\hline $07 \mathrm{ZB}$ & . & . & . & . & . & . & . & . & . \\
\hline $17 \mathrm{ZB}$ & . & . & . & . & . & . & . & . & . \\
\hline $13 \mathrm{ZM}$ & . & . & . & . & . & . & . & . & . \\
\hline $06 \mathrm{ZM}$ & . & . & . & . & . & . & . & . & . \\
\hline $12 \mathrm{ZB}$ & . & . & . & . & . & . & . & . & . \\
\hline $20 \mathrm{ZM}$ & . & . & . & . & . & . & . & . & . \\
\hline $08 \mathrm{ZA}$ & . & . & . & . & . & . & . & . & . \\
\hline $17 \mathrm{ZA}$ & . & . & . & . & . & . & . & . & . \\
\hline $20 \mathrm{ZA}$ & . & . & . & . & . & . & . & . & . \\
\hline
\end{tabular}

Genetic distance matrix of Zebrafish's sequence data in Buyan Lake compared with sequence data on gene bank (Table 3) shows that the samples of Zebrafish in Buyan Lake have a genetic distance of 0 with Amatitlania nigrofasciata KU568740, Amatitlania nigrofasciata KU568739, Amatitlania nigrofasciata KU568737, Amatitlania nigrofasciata KJ552531, and Amatitlania nigrofasciata KU568738.
This indicates that the Zebrafish samples in Buyan Lake are a true Amatitlania nigrofasciata. According to Zamroni et al. (2014) that the genetic distance of 0 means species is derived from the same population. Akbar et al. (2014) also states that the genetic distance of 0.010-0.099 includes low category, 0.1-0.99 includes moderate category, and 1.00-2.00 includes high category.

Certainty of type is necessary in determining the management of a resource. A species that has a morphologically clear taxonomy, it is necessary to do molecular identification to determine the sequence of nucleotide bases. The entire of Zebrafish sequence in Buyan Lake (Table 4) shows that there is no change of base occurring from beginning to the end of base sequence. According to Karmana (2009) mutation very closely related to evolution based on nucleotide sequences.

A phylogenetic tree with a 0.01 scale bar (Figure 3) shows a genetic distance with a nucleotide change of 1 time in every $100 \mathrm{bp}$ (Wardani et al., 2017). The results of the phylogenetic tree analysis of Amatitlania nigrofasciata (Figure 3) obtained one clade. Clade comprises Amatitlania nigrofasciata $07 \mathrm{ZB}$ FISHBCL BD, Amatitlania nigrofasciata $17 \mathrm{ZB}$ FISHBCL BD, Amatitlania nigrofasciata 13 ZM FISHBCH BD, Amatitlania nigrofasciata $06 \mathrm{ZM}$ 
FISHBCL BD, Amatitlania nigrofasciata 12 ZB FISHBCL BD, Amatitlania nigrofasciata 20 ZM FISHBCH BD, Amatitlania nigrofasciata 08 ZA FISHBCL BD, Amatitlania nigrofasciata $17 \mathrm{ZA}$ FISHBCL BD, Amatitlania nigrofasciata 20 ZA FISHBCL BD, Amatitlania nigrofasciata KU568740, Amatitlania nigrofasciata KU568739, Amatitlania nigrofasciata KU568737, Amatitlania nigrofasciata KJ552531, Amatitlania nigrofasciata KU568738, Amatitlania coatepeque KJ820801, Amatitlania siqua KJ820797, Amatitlania coatepeque KJ820809, Amatitlania coatepeque KJ820803 with bootstrap value of 100. Lemey et al. (2009) states that a bootstrap value higher than 70 indicates that the data is relatively stable, it means good in NJ analysis. Outgroup comprises Amphilophus citrinellus JN024798 and Rocio ostofasciata EU751752.

Phylogenetic analysis was clarified with the results of calculating the genetic distance (pairwise distance calculation). It is according to Lante et al. (2011) that the closeness of kinship relation is determined by the genetic distance and the position of accessions that are compared in dendrogram. The furthest genetic distance between the Zebrafish's base sequence in Buyan Lake and the base sequence data on the gene bank of 0.113 (Rocio ostofasciata EU751752) (Table 3). The result of analysis of genetic distance between species from COI locus can be seen that the nearest genetic distance between Zebrafish's base sequence in Buyan Lake (Amatitlania nigrofasciata 07 ZB FISHBCL BD, Amatitlania nigrofasciata 17 ZB FISHBCL BD, Amatitlania nigrofasciata $13 \mathrm{ZM}$ FISHBCH BD, Amatitlania nigrofasciata 06 ZM FISHBCL BD , Amatitlania nigrofasciata 12 ZB FISHBCL BD, Amatitlania nigrofasciata $20 \mathrm{ZM}$ FISHBCH BD, Amatitlania nigrofasciata ZA FISHBCL BD, Amatitlania nigrofasciata 20 ZA FISHBCL BD) with base sequence data on gene bank (Amatitlania nigrofasciata KU568740, Amatitlania nigrofasciata KU568739, Amatitlania nigrofasciata KU568737, Amatitlania nigrofasciata KJ552531, Amatitlania nigrofasciata KU568738) of 0 (Table 3). According to Lante et al. (2011) the smaller genetic distance means has smaller genetic variation and closly kinship with a population. The low genetic distance indicates the uniformity of population. According to Usman (2016) that low genetic distance suggests gene flow between populations. Similarly, the smaller genetic distance between individuals within a population means the more uniformity of that population.
Verawati (2015) states that the value of the genetic distance matrix of 0 has the meaning that in 100 base sequences there are 0 different base. This suggests that the greater value of the genetic distance means the greater difference in the number of nucleotide bases. Conversely, the smaller value of the genetic distance means the less difference in the number of nucleotide bases. The greater difference in the nucleotide sequence means the further of kinship relation. The smaller difference in the nucleotide sequence, indicates that the kinship of each species is closer. According to Pinem et al. (2014), individuals who have small genetic distance indicates a close genetic relationship and individuals who have high genetic distance indicates a distant genetic relationship.

\subsection{Haplotype Diversity}

Zebrafish in Buyan Lake has a haplotype diversity (Hd) of 0.000. Fakhri et al. (2015) states the value of $\mathrm{Hd} \geq 0<0.5$ includes the low haplotype diversity, and $\mathrm{Hd}>0,5 \leq 1$ includes the high haplotype diversity. This value indicates that the presence of Zebrafish in Buyan Lake has a low haplotype diversity. This non-diverse haplotype shows a low level of genetic diversity in a population. Tarwinangsih et al. (2011) states that the high level of genetic diversity can be indicated from the diversity of haplotype $(\mathrm{Hd})$ which is the more diverse haplotypes it shows the higher of the genetic diversity. Ath-thar et al. (2018) states genetic diversity affects the ability of a population to respond to environmental changes. The low haplotype diversity of this study concludes that Zebrafish has less adaptability to environmental changes. Lorenzen et al. (2012) states that high genetic variation indicates a better chance of life, and the ability to passively respond to natural and artificial selection. According to Basyuni et al. (2012) high genetic variation is more resistant to ecological stresses such as unfavorable environmental conditions.

\subsection{Phenotype Characteristic}

Based on the results of morphological measurements obtained Black Zebrafish and Black Zebrafish with Red Spotted are in the same clade with the bootstrap of 94 . Albino Zebrafish and Albino Zebrafish with Red Spotted are in one clade with bootstrap of 99. Based on the morphological dendogram (Figure 4), it shows that Black Zebrafish and Black Zebrafish with Red Spotted are in a 
different clade with Albino Zebrafish and Albino Zebrafish with Red Spotted with bootstrap value of 100. Wirdateti et al. (2016) states the grouping and branching formed are supported by a high bootstrap value that determines the stability of clade. This shows that there is a phenotypic difference between Black Zebrafish, Black Zebrafish with Red Spotted, Albino Zebrafish and Albino Zebrafish with Red Spotted.

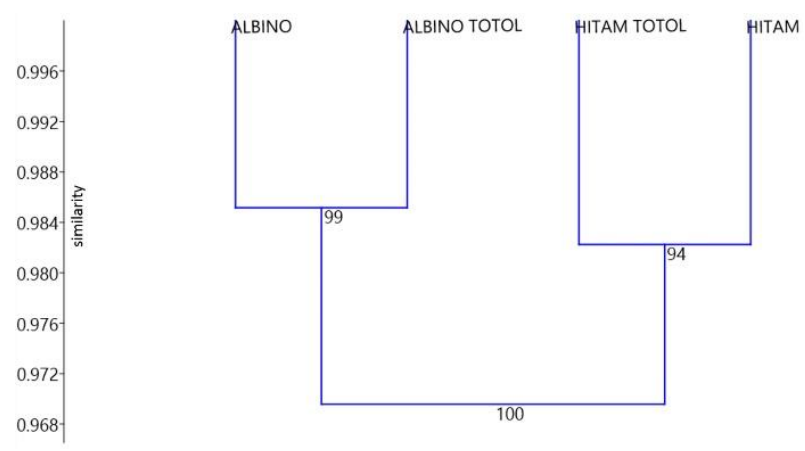

Figure 4. Morphological dendogram

Different phenotypes between individuals are not always indicating that the individual belongs to a different species. Based on this study, Black Zebrafish, Black Zebrafish with Red Spotted, Albino Zebrafish, Albino Zebrafish with Red Spotted are in different phenotypes but they have genotypically similarities. This is evidenced by the the genetic distance calculation of the entire sample of 0. According to Wahab et al. (2014) two individuals who have the same structure and gene sequence do not necessarily have the same phenotype because environmental factors influence the phenotype. In addition, aspects of fish biology and physiology, maternal effects, diet, growth compensation and communal stocking can also affect the different of phenotypes.

\section{Conclusions}

The genetic distance in the entire Zebrafish sequences in Buyan Lake of 0. It means that the sequence of all samples are exactly the same and are truly species of Amatitlania nigrofasciata. Sequence of Zebra Fish in Buyan Lake closely related to Amatitlania nigrofasciata KU568740, Amatitlania nigrofasciata KU568739, Amatitlania nigrofasciata KU568737, Amatitlania nigrofasciata KJ552531, Amatitlania nigrofasciata KU568738 with genetic distance of 0 and has distant relation with Rocio ostofasciata EU751752 with genetic distance of 0.113 (outgroup). The haplotype diversity of Zebrafish sequences in Buyan Lake shows the value of 0 which belongs to a low haplotype diversity. Black Zebrafish and Black Zebrafish with Red Spotted are in a different clade with Albino Zebrafish and Albino Zebrafish with Red Spotted with bootstrap value of 100 which have different phenotypes but they have genotypically similarities with genetic distance calculation of 0 .

\section{Acknowledgement}

The authors wish to acknowledge to all researchers at Laboratory of Biodiversity Indonesia Bali for helping molecular identification and a group of fishermen in Buyan Lake, Buleleng, Bali for helping to collect Zebrafish's sample.

\section{References}

Akbar, N., Zamani, N. P., \& Madduppa, H. H. (2014). Keragaman genetik ikan tuna sirip kuning (Thunnus albacares) dari dua populasi di Laut Maluku, Indonesia. DEPIK Jurnal Ilmu-Ilmu Perairan, Pesisir dan Perikanan, 3(1), 65-73.

Ath-thar, M. H. F., Ambarwati, A., Soelistyowati, D. T., \& Kristanto, A. H. (2018). Keragaman genotipe dan fenotipe ikan uceng Nemacheilus fasciatus (Valenciennes, 1846) asal Bogor, Temanggung, dan Blitar. Jurnal Riset Akuakultur, 13(1), 1-10.

Baldwin, C. C., Mounts, J. H., Smith, D. G., \& Weigt, L. A. (2009). Genetic identification and color descriptions of early life-history stages of Belizean Phaeoptyx and Astrapogon (Teleostei: Apogonidae) with Comments on identification of adult Phaeoptyx. Zootaxa, 2008, 122.

Basyuni, M., Rahayu, S., \& Jayusman. (2012). Studi pendahuluan keragaman genetik spesies yang rentan Johannesteijsmannia altifrons di hutan Sikundur, Sumatera Utara. Indonesian Journal of Forestry, 1(1), 711.

Buhay, J. E. (2009). “COI-Like” sequences are becoming problematic in molecular systematic and DNA barcoding studies. Journal of Crustacean Biology, 29(1), 96-110.

Choudhury, S., Saikia, P., Sougrakpam, N., Brahma, D., \& Dutta, K. (2011). Assessment of morphometric variation and establishing taxonomic relationship among six species under puntius genus. The Ecoscan, 1(1), 233-237.

Fakhri, F., Narayani, I., \& Mahardika, I. G. N. K. (2015). Keragaman genetik ikan cakalang (Katsuwonus pelamis) dari Kabupaten Jembrana dan Karangasem, Bali. Jurnal Biologi, 19(1), 11-14.

Fishbase. (2018). Fishbase [online]. Available at: www.fishbase.org, [diakses: 2 Januari 2018]. 
Hayati, N. (2015). Pemilihan metode yang tepat dalam penelitian (metode kuantitatif dan metode kualitatif). Jurnal Tarbiyah al-Awlad, 4(1), 345-357.

Isda, M. N., \& Chaidamsari, T. (2013). Analisis Sekuen Gen Proteinase Inhibitor (TcPIN) Terkait dengan Ketahanan Terhadap Penggerek Buah Kakao. Dalam Prosiding Semirata FMIPA Universitas Lampung. Lampung, Indonesia, 10-12 Mei 2013 (pp. 97-102).

Karmana, I. W. (2009). Kajian evolusi berbasis urutan nukleotida. GaneÇ Swara, 3(3), 75-81.

Kumar, S., Stecher, G., \& Tamura, K. (2016). MEGA7: molecular evolutionary genetics analysis version 7.0 for bigger datasets. Molecular Biology and Evolution, 33(7), 1870-1874.

Kurniasari, R. D., Soewondo, A., \& Toha, A. H. (2014). Identifikasi Synaptula (Echinodermata: Holothuroidea) Raja Ampat berdasarkan gen COI, Jurnal Biotropika, 2(5), 265-268.

Lante, S., Tenriulo A., Parenrengi, A., Rachmansyah, \& Malina, A. C. (2011). Keragaman genetik populasi ikan beronang (Siganus guttatus) di Selat Makassar dan Teluk Bone menggunakan metode Random Amplified Polymorphic DNA (RAPD). Jurnal Riset Akuakultur, 6(2), 211-224.

Lemey, P., Selemi, M., \& Vandamme, A. M. (2009). The Phylogenetic Handbook: A Practical Approach to Phylogenetic Analysis and Hypothesis Testing. UK: Cambridge University Press.

Lorenzen, K., Beveridge, M. C. M., \& Mangel, M. (2012). Cultured fish: integrative biology and management of domestication and interactions with wild fish. Biology Reviews, 87(3), 639-660.

Mulyadi, M. (2011). Penelitian kuantitatif dan kualitatif serta pemikiran dasar menggabungkannya. Jurnal Studi Komunikasi dan Media, 15(1), 127-138.

Nurhayati. (2008). Studi perbandingan metode sampling antara simple random dengan stratified random. Jurnal Basis Data, 3(1), 18-32.

Nuryadi, W., Rakhmawati, A., \& Prihatini, I. (2016). Isolasi dan identifikasi kapang endofit dari pohon sengon provenan kepulauan Solomon berdasarkan morfologi dan molekuler (analisis rDNA ITS (Internal Transcribed Spacer)). Jurnal Biologi, 5(6), 15-27.

Pinem, U., Hamdan, \& Hanafi, N. D. (2014). Estimasi jarak genetik dan faktor peubah pembeda rumpun kelinci melalui analisis morfometrik. Jurnal Peternakan Intergratif, 2(3), 264-284.

Prabowo, A., \& Heriyanto. (2013). Analisis pemanfaatan buku elektronik (e-book) oleh pemustaka di perpustakaan SMA Negeri 1 Semarang. Jurnal Ilmu Perpustakaan, 2(2), 1-9.

Rahayu, D. A., Listyorini, D., \& Ibrohim. (2013). Morphological study to improve identification toward poeciliidae family based on gonopodium structures and morphometric analysis. Journal of Tropical Life Science, 3(1), 91-95.

Restu, I. W., Kartika, G. R. A., \& Pratiwi, M. A. (2015). Kajian Potensi Sumberdaya Hayati dan Kualitas Air sebagai Indikator Kualitas Lingkungan Danau Buyan dan Tamblingan. Dalam Prosiding Seminar Nasional Sains dan Teknologi II. Bali, Indonesia, 29-30 Oktober 2015 (pp. 1-45).

Samaradivakara, S. P., Hirimuthugoda, N. Y., Gunawardana, R. H. A. N. M., Illeperuma, R. J., Fernandopulle, N. D., De Silva, A. D., \& Alexander, P. A. B. D. (2012). Morphological variation of four Tilapia populations in selected reservoirs in Sri Lanka. Tropical Agricultural Research, 23(2), 105-116.

Sentosa, A. A., \& Wijaya, D. (2013). Potensi invasif ikan zebra cichlid (Amatitlania nigrofasciata Gunther, 1867) di Danau Beratan, Bali ditinjau dari aspek biologinya. Bawal, 5(2), 113-121.

Sravishta, I. M. S. K., Arthana, I. W., \& Pratiwi, M. A. (2017). Pola dan parameter pertumbuhan ikan tangkapan dominan (Oreochromis niloticus, Osteochilus sp. dan Xiphophorus helleri) di Danau Buyan Bali. Journal of Marine and Aquatic Sciences, 4(2), 204-212.

Tarwinangsih, W., Farajallah, A., Sumantri, C., \& Andreas, E. (2011). Analisis Keragaman Genetik Kerbau Lokal (Bubalus bubalis) Berdasarkan Haplotipe DNA Mitokondria. Dalam Prosiding Seminar Nasional dan Teknologi Peternakan dan Veteriner. Bogor, Indonesia 7-8 Juni 2011 (pp. 59-67).

Usman, M. Y. (2016). Analisis Variasi Genetik Ikan Penja Indigenous Perairan Polewali Mandar dan Ikan Nike (Awaous sp.) Indigenous Perairan Gorontalo. Skripsi. Makassar, Indonesia: Fakultas Sains dan Teknologi, UIN Alauddin Makassar.

Verawati, I. (2015). Identifikasi Molekuler, Keragaman Genetik dan Karakteristik Habitat Siput Laut (Nudibranchia) dari Beberapa Populasi di Indonesia. Skripsi. Bogor, Indonesia: Fakultas Perikanan dan Ilmu Kelautan, Institut Pertanian Bogor.

Wahab, M. A., Sundari, \& Suparman. (2014). Kajian kekerabatan filogenetik durian (Durio zibethinus) varietas lokal Ternate berdasarkan karakter morfologi. Jurnal ßIOêduKASI, 2(2), 230-237.

Wardani, M. T., Kudiyantini, E., \& Budiharjo, A. (2017). Identifikasi isolat Monoscus sp hasil isolasi angkak berdasarkan gen Internal Transcribed Spacer (ITS) dan pengukuran kandungan pigmen. Jurnal Biologi, 6(2), 34-40.

Wirdateti, Indriana, E., \& Handayani. (2016). Analisis sekuen DNA mitokondria cytochrome oxidase I (COI) mtDNA pada kukang Indonesia (Nycticebus spp.) sebagai penanda guna pengembangan identifikasi spesies. Jurnal Biologi Indonesia, 12(1), 119-128. 
Wong, E. H. K., \& Hanner, R. H. (2008). DNA barcoding detects market substitution in North American seafood. Food Research International, 41(8), 828-837.

Yang, Z., \& Rannala, B. (2012). Molecular phylogenetics: principles and practice. Nature Reviews Genetics, 13, 303-314.
Zamroni, A., Suwarso, \& Nugroho, E. (2016). Struktur genetika populasi ikan malalugis biru (Decapterus macarellus Cuvier, 1833) di sekitar Sulawesi berdasarkan Mt-DNA marker. Jurnal Penelitian Perikanan Indonesia, 20(1), 31-41.

(C) 2018 by the authors; licensee Udayana University, Indonesia. This article is an open access article distributed under the terms and conditions of the Creative Commons Attribution license (http://creativecommons.org/licenses/by/3.0/). 
